\title{
HALAL GLOBAL ANALYTIC HIERARCHY PARAMETERS: A CONCEPTUAL ASSESSMENT
}

\author{
Rohana Kamaruddin* \\ Hadijah Iberahim, Norlida Abdul Hamid, Rahana Abdul Rahman, Nurol Ain Mustapha \\ Faculty of Business Management \\ Universiti Teknologi MARA \\ Shah Alam, MALAYSIA \\ E-mail: rohana070@ @alam.uitm.edu,my \\ hadijah6553@salam.uitm.edu.my \\ norlida054@salam.uitm.edu.my \\ rahana9019@salam.uitm.edu.my \\ nurol424@salam.uitm.edu.my
}

\begin{abstract}
The dynamic business environment has dramatically changed the structure of logistics industry due to different requirements among the trading nations. One of the emerging and lucrative areas is the halal logistics. The demand towards an effective and acceptable halal logistics services is timely to meet the requirement of international trade of halal products, in particular, the halal food and beverage supplies across the world. The halal food chain is one of the leading industries that aggressively adapting to newly emerging consumer interests like food safety, animal welfare and convenience in cooking and eating. Problems in tracing the authenticity and allocate the source of contamination always delimits the efficacy of the logistics system. To date, no studies look into the global halal logistics performances of the industry. The past studies on tracking movement of imported food (processed) products, reveals a critical level of non compliance among halal logistics operators. In extension, this paper aims to determine criteria of behavior among global halal logistics players. The study will employ analytic hierarchy process (AHP) in determining halal logistics parameters (HAHP). The HAHP based approach will analyze continuous logistics process of the supply chain covering outbound and inbound activities and provides the conceptual elements for the earlier assessment of the industry involved. This study hopes to establish a Halal Global Logistics Index (HGLI) parameters. HGLI measures interindustry and indicates the level of compliance. The index makes it possible to rank industries taking into account the supply chain activities from farm to fork.
\end{abstract}

Keywords: halal, logistics, supply chain, hierarchy, parameters

\section{Introduction}

Globalization intensifies competition along the supply chain to secure food. The new market trends have put the food and beverage industry in a more critical position. The importance of the food and beverage industry requires enhancement in terms of productivity while maintaining a competitive edge. In 2010, global halal food market valued at US\$634 billion (excluding factors such as the amount of non-food consumables, the services sector, spin-off and ancillary activities, and the crossover market for non-Muslim consumers) while increasing purchasing power of Muslims (Abdul Malik, 2010). Its importance is even felt with the increase in the awareness and the demand for halal food and beverage market, including that of non-Muslim dominated countries such as England and Wales (William Reed Business Media Ltd, 2013; Eblex, 2010; Muhammad and Isa, 2009). It has been estimated that about $67 \%$ of the potential halal products are categorized as fast moving consumer goods (FMCG). Both the FMCG together with the primary meat sectors account for $62 \%$ of the market (Halal Development Corporation, 2009).

\footnotetext{
${ }^{*}$ Corresponding author
} 
Many governments play their roles including Malaysia: leader in developing the Halal industry and the best example in the world in terms of rationalization for the labeling of Halal food. Malaysia established International Halal Integrity Alliance Ltd (IHI Alliance) on 30th April 2007 in Labuan by OIC, introduced international halal hubs (IHHs) such as Penang International Halal Hub (PIHH), islamic financial market, Islamic share trading - Sharia Ummah Securities Information Exchange Ltd (ShariaUMEX), global standards such as Halal Standard MS1500:2004, Halal certifications (MS 1900), Halal Logistics Standards MS 1500:2009, Halalan-Toyyiban Assurance Pipeline (HTAPS) MS 2004:2010, International Halal Logistics Standard (IHIAS 0100:2010) by IHI Alliance (Abdul Malik, 2010; Marco, 2012). Other countries includes Thailand, known World's Halal Kitchen - fifth largest halal food exporter and recognized as Halal centre of excellence in science and testing; Europe: European Halal Distribution Centre at Port of Rotterdam and Super Halal Industrial Park (SHIP) at South Wales that worth $£ 150 \mathrm{~m}$ to cater demand of 30 Million Muslims. Singapore encourage on $100 \%$ halal for food including at Mc Donald's, A\&W, KFC and Taco Bell (Abdul Malik, 2010).

In response to the growing lucrative and influential demand for halal products, it is apparent that the increasing number of halal operators exerts to be certified and recognized as halal compliance by integrating into halal logistics system. This may be seen in the recent trends, whereby global industrial players including Nestle (world's largest food manufacturing corporation), McDonalds (the world's largest leading restaurant chain), KFC (fully integrated poultry chain), Tesco \& Carrefour (world's number one $\&$ two retail chain), Port Rotterdam (Europe's largest $\&$ the world's $3^{\text {rd }}$ largest port), Westports (one of SEA top 10 ports), MISC (the world second biggest shipping company), CIMB (SEA biggest investment bank), Allanasons (India's biggest meat exporter) and Al-Islami (UAE halal food producers) have started to engage to halal logistics (eg. Abdul Malik, 2010; R. Kamaruddin, H. Iberahim, A. Shabudin, 2012). Studies also found that increase awareness among Muslim and nonMuslim on Halal product has supported the willingness to pay for halal products (R. Kamaruddin, H. Iberahim, A. Shabudin, 2012). With huge purchasing power among Non-Muslim countries, confidence on halal branding due to healthy, wholesome, hygiene and safety products/services as underlines by the syariah principles (Abdul Malik, 2010; Harlina Suzana et al, 2011).

\subsection{Issues and challenges in halal logistics industry}

Towards understanding the halal logistics through the supply chain management, the halal logistics sector in Malaysia is very diverse and covers various sectors of the chain management. Halal logistics is the process of managing the procurement, movement, storage and handling of materials, parts livestock and (semi) finished inventory both food and non-food (and related information and documentation flows) through the organization and the supply chain in compliance with the general principles of Shariah Law (MITRANS, 2012). Halal logistics is where the Shariah is being applied to the logistics discipline.

The main objective of halal logistics is to ensure the halal integrity of halal products for the endconsumer and is generally defined as the command and control of goods flows in a value system in such a way that the halal integrity is secured throughout the supply chain. The scope of halal logistics covers the halal logistics hub, transport, route as well as management (ibid). Halal logistics solutions for issues in halal industry, whereby success in logistics service management capabilities determine the integrity of Halal products by eliminating the risk of cross contamination during transportation, storage and handling. Thus, the needs to maintain the Halal performance responsibility during transportation process is deem vital (Harlina Suzana et al., 2011; Mohd Iskandar Illyas et al., 2012).

The halal supply chain is perhaps becoming the most important component of the logistic function. Innovation in logistics service providers is important to gain competitive advantage - halal supply chain is focusing on traceability, which applies the technological tools for traceability - portrays the requirements and procedures involved to produce the halal logistics service. (Harlina Suzana et al, 2011). Some of the influential criteria in the selection of halal supply chain solution based on the finding in tracking movement of imported processed food (processed) products by R. Kamaruddin, Iberahim, H., A. Shabudin (2011). The halal status is only gained when the concept is fully 
implemented, referring to the entire activities along the supply chain, namely sourcing, manufacturing, transportation, storage/warehousing and handling. Halal compliance is critical at the point of the outbound from the producers to exporters where storage, palletizing, transporting and containerization activities take place. Similar activities are critical at the inbound from Malaysia port terminal to Muslim customers in Malaysia. Figure 1 summarized the halal compliance critical control points.

Figure 1: Halal Traceability for Malaysia bound Products.

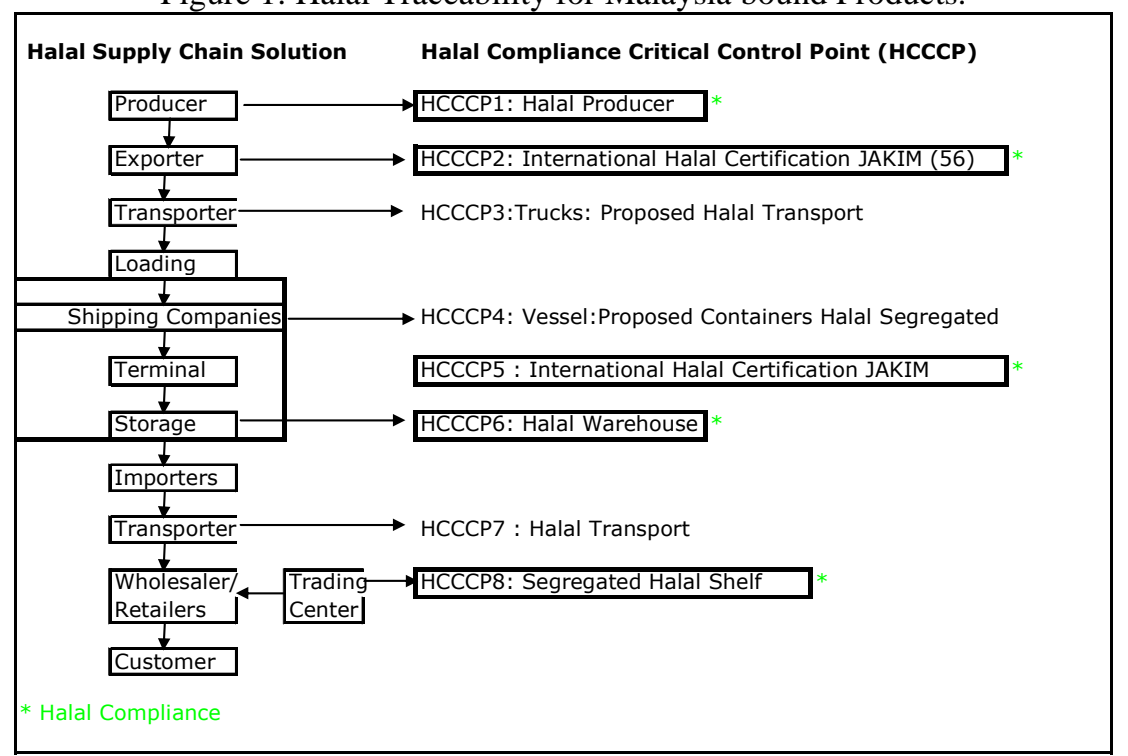

Source: Halal Compliance Critical Control Point (HCCCP), 2011, R.Kamaruddin, H.Iberahim \& A. Shabudin (2011)

With reference to Figure 1, past study shows that it is quite impossible to achieve a complete halal compliance of the supply chain solution. Halal compliance monitoring is needed at every point of transfer. The study noted that out of 8 points, 3 points of transportation which are trucking from exporter's place to the port, vessel carrying cargo from the point of export and the trucking from the port to the importer's place may not be carried out by a halal carrier. Risk to contamination due to sharing containers, poor visibility into what inventory is in which containers, where the container is transit, history of immediate suppliers, history of immediate maintenance and segregation allocation space between Halal and non-Halal goods in same containers increased the risk toward Halal integrity being compromised (Darhim, 2010)

\subsection{Global halal certification and regulatory issues}

Studies show some inconsistent assessment on halal logistics and halal principles (H. Iberahim, R. Kamaruddin, A. Shabudin, 2012). Halal is known as a religious issue which explained the reason why there are less state intervention on halal development. Regulation stated under the labeling law addresses halal certification conducted by many agencies/ associations/ councils/ federations. Thus, to date, there is still no unified Halal standard and logo that may be applicable across the world. This inconsistence and no unified standards lead to two main problems which are i) contamination and ii) abuse (Marco, 2012; Darhim, 2010). Many studies propose that segregation of halal and non-halal goods through the transportation, storage, and (sea/air/ rail/inland) terminal operations may avoid (cross) contamination, mishandling, ensuring that operations are consistent with the expectations of the Muslim consumers. In halal logistics it is important to know the segregation levels formulated as consumer requirements during transportation, warehousing, shipment and in the supermarket (Marco, 2012). For instance, abuse of halal certification refers to lack of understanding of halal such as the case of mislabeling that says "pork free" and "slaughtered according to Islamic rites" were found in UAE. The contradiction of terms indicates a lack of understanding of halal on the part of producer. In other cases, the abuse of halal logo "Pasar Fresh Pork (Air Flown)" with MUIS Halal logo are found in Singapore. There are some fundamental differences and variances in interpretation of halal across 
member states resulting in unresolved issues which are the definition of halal versus the use of the word halal (Darhim, 2010).

These findings appeal an urgent need for an approach to assess the current development of halal logistics among players in ensuring the halal global standard. Perhaps, a Halal Global Logistics Index (HGLI) parameters has to be established to accommodate the missing links.

\section{Analytic Hierarchy Process in Deciding Halal Logistics Criteria}

Analytic Hierarchy Process (AHP) has been an effective tool for decision makers and researchers and is one of the most widely used multiple criteria decision-making tools (Vaidya and Kumar, 2006). Its wide application cuts across various different fields such as planning, selecting a best alternative, resource allocations, resolving conflict, optimization and numerical extensions of AHP. What made AHP very unique and special is its flexibility to be integrated with different techniques such as Linear Programming, Fuzzy Logic and others (ibid). Such flexibility thus enables the user to gain benefits from the various combined method, then on achieving the goal in a much effective manner. It simply directs how to determine the priority of a set of alternatives and the relative importance of attributes in a multiple criteria decision-making problem.

Within the logistics and the supply chain industry, the use of the AHP has been quite diverse. One such work is that of Wei, Chien and Wang (2005) whereby they depended on AHP to assist them in selecting a suitable Enterprise Resource Planning (ERP) system for the integration of the flow of materials, finance and information in supporting the organizational strategies of their company. Wang, Huang and Dismukes (2004) depended on the use of the integrated AHP and preemptive goal programming (PGP) based multi-criteria decision-making methodology to account for both the qualitative and quantitative factors in the supplier selection of the supply chain design. This had resulted in the AHP process matched the product characteristics with supplier characteristics to quantitatively determine supply chain strategy while PGP determined the optimal order quantity from the chosen suppliers. The work of Korpela, Kylaheiko, Lehmusvaara and Tuominen (2002) have successfully applied AHP in developing a framework whereby the target was to prepare a sales plan where the limited production capacity is allocated to the customers based on their strategic importance and the risk involved. The overall supply chain is designed on the basis of the customers' strategic importance and service requirements.

The use of AHP in assisting decision makers in evaluating and selecting suppliers in an effective supply chain can be traced in the work of Shahroodi, Keramatpanah, Amini, Shiri, Sayyas and Najibzadeh (2012). On a rather similar note, towards selecting a third-party reverse logistics providers, Saen (2009) applied AHP in the process. Saen (2009) however highlighted two main weaknesses of AHP (and Analytic Network Process (ANP)). First subjectivity of ANP is a weakness. The decision maker provides the value for the pairwise comparisons and therefore the model is very dependent on the weightings provided by the decision maker. Secondly, the time necessary for completion of such a model is a weakness. The number of pairwise comparisons required could become cumbersome. Meanwhile, when the number of alternatives and criteria grows, the pairwise comparison process becomes difficult, and the risk of generating inconsistencies grows, hence jeopardizing the practical applicability of AHP (and ANP).

Overall through the work of Vaidya and Kumar (2006), although it has been stated that AHP will be widely used in decision-makings and that its application will be seen more in the developing countries, but none of the their reviews on its application are in the area of halal logistics. Hence this gives a strong motivation for this study to be carried out within the context of halal logistics focusing on the food and beverage industry. The current scenario hence requires that every stage of the logistics and the supply chain management of the food and beverage industry to be effective and efficient. This includes any aspects of its decision-making process that relates to both the qualitative and quantitative assessment of the industry performance. One such decision-making tool is the AHP, developed by Thomas L. Saaty (2008). 


\section{A Proposed Conceptual Framework for Halal Global Assessment}

Thus a technique is needed that can capture both subjective and objective evaluation measures. The AHP is a decision making for ranking the alternatives compliance point when multiple criteria must be considered. AHP is a decision making method for prioritizing alternatives when multiple criteria must be considered. In this case, we would like to apply in the area of halal logistic for evaluating index formulations. This method allows researchers to structure complex problems in the form of hierarchy, or a set of integrated levels.

Generally halal index formulation has at least three levels: the goals, the compliance criteria and the alternatives. The process begins by determining the relative importance of the halal compliance criteria in the supply chain process. Next, the focus shifts to measuring the extent to which the alternatives achieve each of the criteria. Finally, the results of the two analyses are synthesized to compute the relative importance of alternatives in meeting the goal from the perspective of logistic players and customer.

Figure 2. Criteria for Compliance of Halal Selection

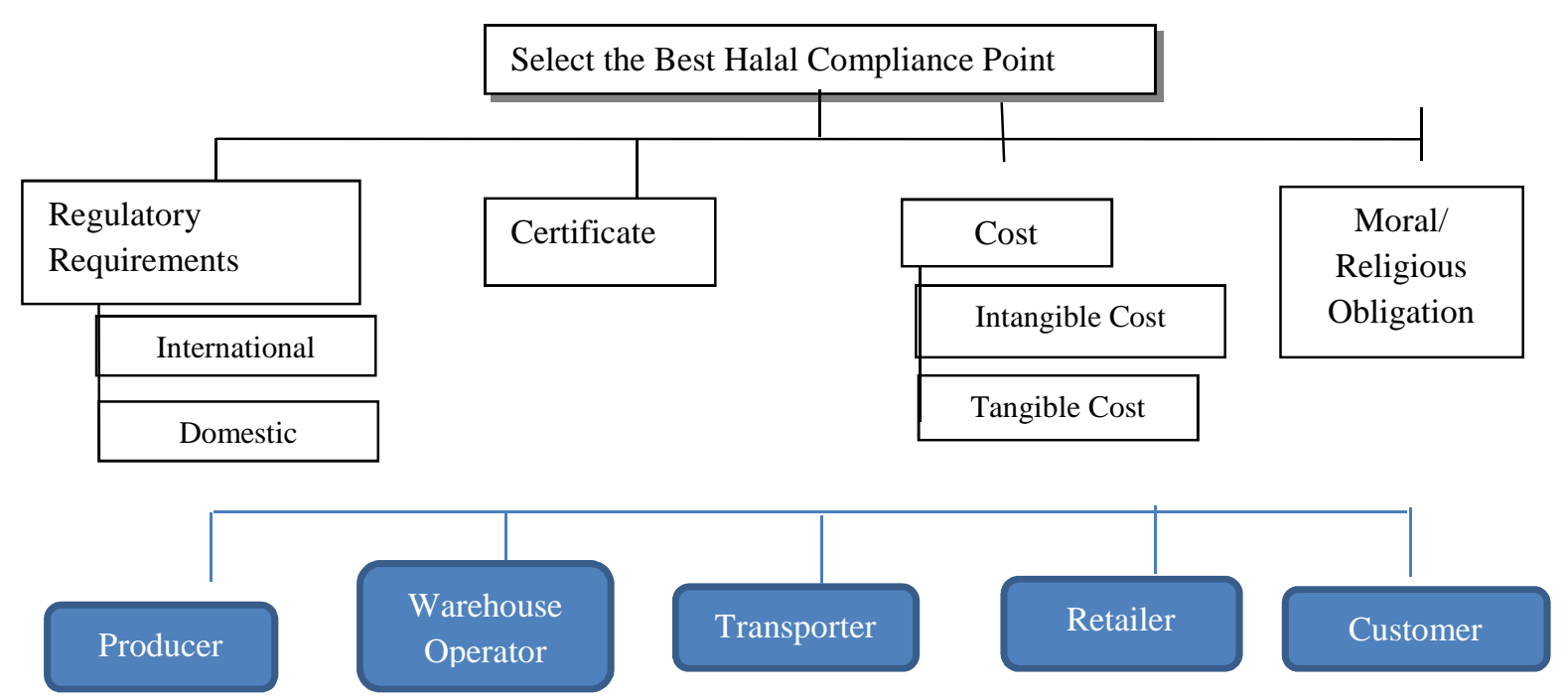

The goal of the study is to identify the best halal compliance point in order to ensure the delivery of halal product in the supply chain. There are four criteria which may determine the decision to engage in halal supply chain; 1) the regulatory requirements at international and/or local market, 2) the certification of halal acquired from recognized institution, 3) the intangible and tangible cost incurred in the operations and 4) the obligation towards moral and religious. In regards to the sub criteria, the study looks into the priorities between sub criteria and parent criterion to obtain their global priorities. There are five parties which play important role in respond to halal compliance such as the producer, the warehouse operator, the transporter, the retailer and the customer as end user. The aim is to discover the most challenging factor and comparatively important player in the halal supply chain.

\subsection{Methodology}

This study would like to utilize a pairwise comparison by using a divide-and conquer problem solving method. This method allows one to determine the relative order (ranking) of a group of criteria and often used as part of a process of assigning weights to criteria in design concept in halal compliance 
point. One compares the critical points and players position in order to clarify the point of halal compliance. Justification will be made in comparing how many times more, or how strongly more that point of halal compliance than the other is. In order to justify the degree of importance and dominance an element over another element with respect to the criterion or property with respect to which they are compared, Table 1 presents the scale.

Table 1. Measurement Scale

\begin{tabular}{|l|l|}
\hline $\begin{array}{l}\text { Intensity of } \\
\text { Importance }\end{array}$ & Verbal Judgment or Preference \\
\hline 1 & Equal importance \\
\hline 2 & Weak or slight \\
\hline 3 & Moderate importance \\
\hline 4 & Moderate plus \\
\hline 5 & Strong importance \\
\hline 6 & Strong plus \\
\hline 7 & Very strong or demonstrated importance \\
\hline 8 & Very, very strong \\
\hline 9 & Extreme importance \\
\hline $1.1-1.9$ & If the activities are very close \\
\hline $\begin{array}{l}\text { Reciprocal: If activity i has a specific numerical rating with } \\
\text { respect to activity j, then } \mathrm{j} \text { has the reciprocal value when } \\
\text { compared to i }\end{array}$ \\
\hline
\end{tabular}

Source: adopted from Saaty (2008)

Saaty (2008) suggests that a possible way to making decision is to study that entity relative to other similar entities and relate it to them by making comparisons. The AHP offers a methodology to examine alternatives courses of action based on the decision makers' judgments concerning the importance of the criteria and the extent to which they are met by each alternative. Thus, this study adopts relative model. For these reason, the conduct of pairwise comparison for the halal compliance steps are as follow:

Step 1: Identify the criteria to be ranked

Step 2: Arrange the criteria in a pairwise comparison matrix

Step3: Compare pairs of criterion

Step 4: Create the ranking of criterion

Step 5: Calculating the actual weights for each compared criterion

The pairwise comparison information for each criterion will be represented by a pairwise comparison matrix. The comparison process need to be conducted for level 1 criteria, the sub-criteria at level 2 and alternatives at level 3 in accordance to the Figure 2. It is vital to ensure that the priorities for each matrix will contribute to the single overall priorities and ranking in obtaining an accurate relative model where alternatives are compared with each other under various criteria.

\subsection{Problem statement}

Previous studies on the use of AHP focus on a wide variety of application areas such as engineering, education, social, political and government, as can be seen in the works of Vaidya and Kumar (2006). Even though there are applications on the areas on manufacturing, but there is yet no indication on the application of AHP in the area of halal logistics. Given the depth of the scope of the Halal-Toyyiban principles and parameters within the food and beverage industry alone, encompassing both the qualitative and quantitative factors, there is a need then to explore further such applications. The rationale for this study is further compounded by the rapid rise in the demand for halal-based food and beverage among both Muslims and non-Muslims dominated countries. The past tracking study by Kamaruddin, Iberahim and Shahbudin (2012) that revealed a critical level of non compliance among halal logistics operators further strengthened the rationale. 


\section{Summary and Conclusion}

The application of AHP in assisting the decisions to be made with regard to determining halal logistics parameters (HAHP) for the halal logistics and supply chain activities within the food and beverage industry has further given some insights into the scope of the tangible and intangible as well as the quantitative and qualitative aspects of the halal logistics aspects to the industry. It is hoped that the identified parameters will now lead to the development of an acceptable and comprehensive global halal logistic index for the market at large.

\section{Acknowledgements}

This study was conducted under the project titled "Halal Compliance Critical Control Point Assessment Using Analytical Hierarchy Parameters", funded by Institution of Higher Education, Malaysia, grant secured under Exploratory Research Grant 2012.

\section{REFERENCES}

Abdul Malik Kassim (2010). The Global market potential of Halal. International Conference \& Expo on Halal Industry. Lahore, Pakistan (9 August 2010). Halal Research Council Conference: Lahore, Pakistan.

Darhim D. Hashim (2010). The Quest For A Global Halal Standard. Meat Industry Association of New Zealand (Inc) Annual Conferencechateauon at The Park, Christchurch, 19 -20 September 2010

Darhim Hashimi and Shaikh Mohd Saifuddeen Shaikh Mohd Salleh (2012). A Background on Halal Industry and Principles. International Workshop for Islamic Scholars on Agribiotechnology: Shariah Compliance. Georgetown, Penang, Malaysia (1-2 December 2010). Malaysia Biotechnology Information Center: Selangor, Malaysia; International Service for the Acquisition of Agri-biotech Applications: Los Baños, Laguna, Philippines.

Eblex (2010). The Halal meat market: Specialist supply chain structures and consumer purchase and consumption profiles in England. Available from http://www.eblextrade.co.uk/books/the-halal-meatmarket/files/assets/basic-html/toc.html Accessed on 10/02/2013.

Halal Development Corporation (2009). HDC VIBE (2009). Available from http://elib.uum.edu.my/kip/Record/upm027009143. Accessed on 10/02/2013.

Harlina Suzana Jaafar, Intan Rohani Endut, Nasruddin Faisol and Emi N Omar (2011) Innovation in Logistics Services: Halal Logistics. Proceedings of the 16th International Symposium on Logistics (ISL), Berlin, Germany, 10-13 July, pp 844-851. ISBN:978-085358-279-3

K. Rohana, Iberahim, H. \& Shabudin, A. (2012).Willingness to Pay for Halal Logistics: The Choice of Lifestyle. Proceedings of the ASEAN Conference on Environment-Behaviour Studies (AcE-Bs 2012). Bangkok, Thailand, July 16-18.

K. Rohana, Iberahim, H., \& Shabudin, A. (2012). Halal Compliance Critical Control Point (HCCCP) Analysis of Processed Food. Proceedings of the 2012 Business, Engineering \& Industrial Applications Colloquium (BEIAC). Kuala Lumpur, April. 383-387.

Korpela,J, Kylaheiko,K., Lehmusvaara,A. and Tuominen,M. (2002). An analytic approach to production capacity allocation and supply chain design. International Journal of Production Economics, 78, $187-195$. 
Marco Tieman, Jack G.A.J. van der Vorst, Maznah Che Ghazali, (2012) "Principles in halal supply chain management", Journal of Islamic Marketing, Vol. 3 Iss: 3, pp.217 - 243

MITRANS (2012). The Value and Advantage of Halal Logistics .In Halal Logistics Conference 2012, $28^{\text {th }}$ June 2012, Traders Hotel, Penang, Malaysia. Available fromhttps:www.hdcglobal.com/uploadweb/cms-editor-files/21bc5b40-5eff-40e8-b4f

5b6a20931fed/file/The $\% 2520$ Value $\% 2520$ and $\% 2520$ Advantage $\% 2520$ of $\% 2520$ Halal\% 2520 Logistics _AZLINA.pdf . Accessed on 15/02/2013.

Mohd Iskandar Illyas Tan, Raziah Noor Razaliand Zuhra Junaida Husny (2012) The Adoption of Halal Transportations Technologies for Halal Logistics Service Providers in Malaysia. World Academy of Science, Engineering and Technology, Vol 63.

Muhammad, N and Isa, F. M. (2009). Positioning Malaysia as Halal-Hub: Integration Role of Supply Chain Strategy and Halal Assurance System. Asian Social Science, Vol.5, No.7 ,44 - 52.

Nik Maheran Nik Muhammad, Filzah Md Isa, Bidin Chee Kifli (2009). Positioning Malaysia as Halal-Hub: Integration Role of Supply Chain Strategy and Halal Assurance System. Asian Social Science Vol 5, No 7, July, 2009

Saaty, T.L.(2008). Decision making with the analytic hierarchy process. International Journal Services Sciences, 1 (1), 83-98.

Saen,R.F. (2009). A Mathematical Model for Selecting Third Party Reverse Logistics Providers. International Journal of Procurement Management, np.

Shahroodi, K.,Keramatpanah, A.,Amini, S.,Shiri, E.,Sayyad,H. and Najibzadeh,M. (2012). Kuwait Chapter of Arabian Journal of Business and Management Review, 1,8. 1-14.

Suhaiza Zailani, Zainal Arrifin, Nabsiah Abd Wahid, Rosly Othman and Yudi Fernando.(2010). Halal Traceability and Halal Tracking Systems in Strengthening Halal Food Supply Chain for Food Industry in Malaysia (A Review). Journal of Food Technology. Volume: 8, Issue: 3, Page No.: 74-81

Vaidya, O,S. and Kumar, S. (2006). Analytic Hierarchy Process: An Overview of Applications. European Journal of Operational Research, 169, 1-29.

Wang, G., Huang, S. H. and Dismukes, J.P. (2004). Product-driven supply chain selection using integrated multi-criteria decision-making methodology. International Journal of Production Economics, 91, 1-15.

Wei, C., Chien, C and Wang, M. (2005). An AHP-based approach to ERP system selection. International Journal of Production Economics, 96, 47-62.

William Reed Business Media Ltd (2013). Growing halal meat market calls for new research Available from http://www.meatinfo.co.uk/news/fullstory.php/aid/15180. Accessed on 12/02/2013. 